\title{
EVALUATION OF THE ENGINEERING PROPERTIES OF FLY ASH-BASED GEOPOLYMER BRICKS
}

\author{
Si-Huy Ngo \\ Department of Engineering and Technology, Hong Duc University, Viet Nam
}

\begin{abstract}
This paper is aimed to evaluate the engineering properties of fly ash-based geopolymer bricks. Four geopolymer brick mixtures were designed with a constant solution-to-binder ratio of 0.40 and various concentrations of sodium hydroxide solution. The engineering properties of fly ash-based geopolymer bricks consisting of compressive strength, unit weight, water absorption, water permeability, and ultrasonic pulse velocity were investigated. The microstructure of fly ash-based geopolymer bricks was also investigated by using the scanning electron microscope (SEM). Test results indicated that the compressive strength, unit weight, and ultrasonic pulse velocity (UPV) of geopolymer bricks increased, while the water absorption and water permeability of geopolymer bricks reduced with increasing $\mathrm{NaOH}$ concentration. Moreover, brick samples with high $\mathrm{NaOH}$ concentration showed a higher geopolymeric reaction of fly ash than brick samples with low $\mathrm{NaOH}$ concentration. All geopolymer brick samples produced in this study showed a good quality with compressive strength of above $10.1 \mathrm{MPa}$, water absorption of below $9.4 \%$, water permeability of below $1.84 \mathrm{~L} / \mathrm{m}^{2} . h$, and UPV of above $2500 \mathrm{~m} / \mathrm{s}$.
\end{abstract}

Keywords: brick, compressive strength, fly ash, geopolymer, sodium hydroxide, ultrasonic pulse velocity, water absorption, water permeability.

Cite this Article: Si-Huy Ngo, Evaluation of the Engineering Properties of Fly AshBased Geopolymer Bricks. International Journal of Civil Engineering and Technology, 11(2), 2020, 43-51.

https://iaeme.com/Home/issue/IJCIET?Volume=11\&Issue=2

\section{INTRODUCTION}

Cement-based products are well-known as the second most used material in the world after water [1]. A large quantity of cement-based products, as well as cement, is annually generated, and it is still increasing due to the growth of population and human living conditions. However, the production of cement consumed an intensive amount of energy and released a large volume of greenhouse gases, significantly negatively impacting the environment. It was also a cause for the depletion of natural resources. Recently, geopolymer products have been found as an alternative solution to replace cement-based products [2-5]. It was concluded that geopolymer products had comparable or even better properties and lower 
global warming potential than cement-based products. Those were also considered as costeffective and green construction materials [6]. One of the potentials to replace cement is fly ash, a by-product of coal power plants. With a high content of silicon dioxide $\left(\mathrm{SiO}_{2}\right)$ and aluminum oxide $\left(\mathrm{Al}_{2} \mathrm{O}_{3}\right)$, fly ash is suitable utilization as an alkali-activated binder instead of cement in construction materials. Furthermore, the store of fly ash is large enough for the construction industry. In Vietnam, it is projected that 29 million tons of fly ash and bottom ash are released annually [7]. In which, amount of fly ash is a majority with about 80 percentages. Such amount of these ash stockpiled on landfills caused many problems related to air and water pollutions, agricultural land loss, and human health. Thus, the reuse of fly ash as a construction material gives both benefits in economics and the environment.

The use of fly ash as an alkali-activated binder was attractive to many researchers. With the activation of sodium hydroxide, Memon et al. [8] have successfully used fly ash as a binder material in self-compacting concrete. The application of fly ash in the mortar was also investigated in previous studies [9-11], in which fly ash was activated by a combination of sodium hydroxide and sodium silicate. It is worth noting that the compressive strength of mortar can reach to $50 \mathrm{MPa}$ [11] if using a suitable ratio between the sodium hydroxide and sodium silicate solutions. Similarly, fly ash was also utilized to produce geopolymer pastes $[10,12-16]$. Test results indicated that it was possible to produce a geopolymer paste incorporating fly ash with a compressive strength of $56 \mathrm{MPa}$ [12]. The compressive strength and flexural strength of geopolymer pastes containing both fly ash and ground granulated blast furnace slag can reach to $100 \mathrm{MPa}$ [15]. However, the different results were found for the influence of $\mathrm{NaOH}$ concentration on the compressive strength of pastes. Most of the studies stated that the compressive strength of geopolymer pastes increased with increasing $\mathrm{NaOH}$ concentration $[10,12,13]$, whereas Somna et al. [16] reported that $\mathrm{NaOH}$ concentration exceeding $14 \mathrm{M}$ led to a reduction in compressive strength of paste. That may be due to the various quality of fly ash used in those studies [17-18].

Moreover, fly ash was also applied to produce geopolymer bricks. The paving blocks produced from fly ash and red mud under activation of $\mathrm{NaOH}$ solution had a compressive strength of above $16 \mathrm{MPa}$ and water absorption of 6.0-7.0\% [19]. Freidin [20] investigated the use of fly ash, bottom ash, and water glass as an alkaline activator to produce pressed blocks. The experimental results showed that the compressive strength and water absorption of pressed blocks ranged from 1.5-15.6 $\mathrm{MPa}$ and 5.8-38.4\%, respectively. Furthermore, the geopolymer method was used to produce unfired building bricks containing fly ash, ground and unground rice husk ash, and sand under activation of sodium silicate and sodium hydroxide solutions [21-23]. Test results indicated that the engineering properties of those bricks conformed to the Vietnamese standard for unfired building bricks with compressive strength of above $20 \mathrm{MPa}$. The fly ash and $\mathrm{NaOH}$ of $10 \mathrm{M}$ were used as activated-binder materials to produce unfired building bricks incorporating chippings and unground rice husk ash [7]. The compressive strength and water absorption of these bricks were 1.5-29 MPa and $3.7-31.9 \%$, respectively.

Recycling fly ash as a binder material into geopolymer products such as concrete, mortar, paste, and brick has been studied by many researchers as mentioned above; however the database for geopolymer bricks is still limited. The objective of this study is to investigate the use of fly ash for the production of geopolymer bricks. The physical, mechanical, durable properties and microstructure of geopolymer bricks were examined. The influence of sodium hydroxide concentrations on engineering properties of fly ash-based geopolymer bricks was also investigated. 


\section{MATERIALS AND EXPERIMENTAL PROGRAMS}

\subsection{Materials}

Geopolymer bricks in this study were manufactured from fly ash, chippings, and sodium hydroxide solution. Fly ash was locally sourced from a coal power plant in Thanh Hoa province of Viet Nam. The chemical composition and density of fly ash are shown in Table 1. According to ASTM C618 [24], it is classified as Class-F because of the total amount of silicon dioxide, aluminum oxide, and iron oxide greater than $70 \%$. The scanning electron micrograph of fly ash is shown in Figure 1. The spherical shapes in various sizes are fly ash particles, while irregular shapes maybe are unburnt impurities. It is explained for high loss on ignition of fly ash (15.9\%).

Chippings, which is a by-product from the process of stone crushing, was used as a fine aggregate in this study. The specific gravity, dry rodded weight, maximum size, fineness modulus, and water absorption of chippings are $2.69,1.62 \mathrm{~T} / \mathrm{m}^{3}, 5 \mathrm{~mm}, 3.39$, and $1.08 \%$, respectively. Figure 2 shows the gradation curve of chippings. The sodium hydroxide solution was utilized to activate the fly ash. The concentrations of sodium hydroxide solutions are 5,8 , 10 , and $12 \mathrm{M}$ corresponding to their densities of $1.20,1.28,1.33$, and $1.38 \mathrm{~T} / \mathrm{m}^{3}$.

Table 1 Chemical composition and density of fly ash

\begin{tabular}{lcccccccc}
\hline Composition (wt.\%) & $\mathrm{SiO}_{2}$ & $\mathrm{Al}_{2} \mathrm{O}_{3}$ & $\mathrm{Fe}_{2} \mathrm{O}_{3}$ & $\mathrm{CaO}$ & $\mathrm{MgO}$ & Others & LOI & Density \\
\hline Fly ash & 51.5 & 20.2 & 7.07 & 1.99 & 1.23 & 2.16 & 15.9 & 2.16 \\
\hline
\end{tabular}

$*$ LOI $=$ Loss on ignition

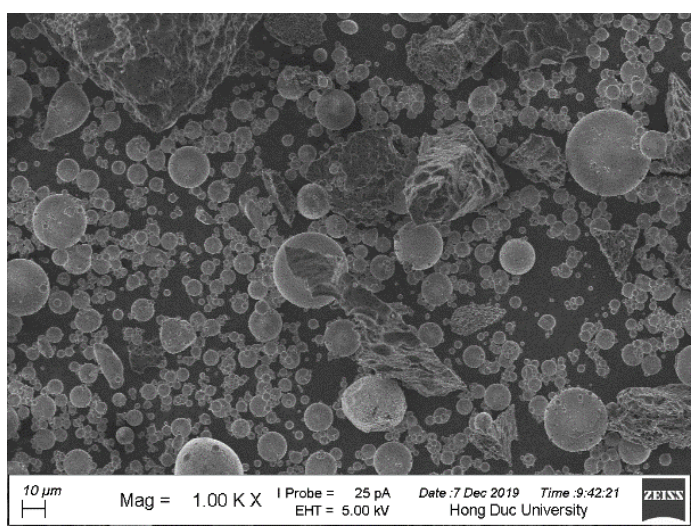

Figure 1. Scanning electron micrograph image of fly ash

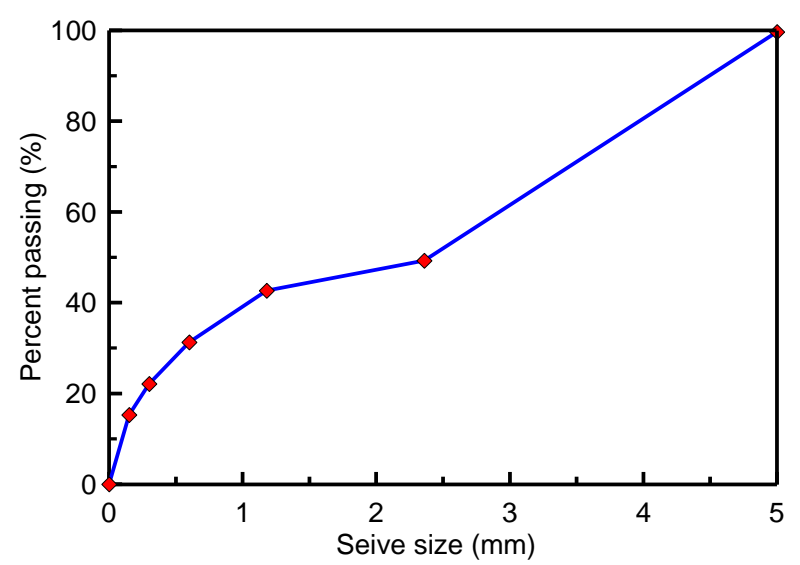

Figure 2. Gradation curve of chippings

\subsection{Brick Mixtures}

Table 2 shows mixture proportions for all fly ash-based geopolymer bricks. Four mixtures were designed with a fixed sodium hydroxide solution-to-binder ratio (S/B) of 0.4 , referred to $\mathrm{B} 40$ in the nomenclature of mixtures. These numbers 5, 8, 10, and 12 following B40 denote concentrations of $\mathrm{NaOH}$ solution. The purpose of this design is to investigate the influence of $\mathrm{NaOH}$ concentrations on the engineering properties of fly ash-based geopolymers bricks. It is noticed that the amount of fly ash and $\mathrm{NaOH}$ solution were fixed to ensure a constant $\mathrm{S} / \mathrm{B}$ ratio of 0.4 , whereas the chippings content in each mixture varied to remain the total volume of all ingredients in one cubic meter. That is due to the various density of $\mathrm{NaOH}$ solution corresponding to different $\mathrm{NaOH}$ concentrations. 
Evaluation of the Engineering Properties of Fly Ash-Based Geopolymer Bricks

Table 2 Mixture proportions for sample preparation

\begin{tabular}{ccccc}
\hline \multirow{2}{*}{ Mixture } & \multirow{2}{*}{ S/B } & \multicolumn{3}{c}{ Ingredient proportions $\left(\mathbf{k g} / \mathbf{m}^{\mathbf{3}}\right)$} \\
\cline { 3 - 5 } & & Fly ash & Chippings & NaOH solution \\
\hline B40-5 & & 1833 & \\
B40-8 & \multirow{2}{*}{0.40} & \multirow{2}{*}{400.0} & 1856 & 160 \\
B40-10 & & & 1868 & \\
B40-12 & & & 1880 & \\
\hline
\end{tabular}

\subsection{Samples Preparation and Test Programs}

To produce geopolymer brick samples, fly ash was firstly mixed with sodium hydroxide solution to form a geopolymer paste. After that, chippings were added to the paste and continued mixing until the mixture becomes homogeneous. A steel mold with dimensions of $160 \times 85 \times 40 \mathrm{~mm}$ was used to form brick samples. A pressure of around $0.5 \mathrm{MPa}$ was used during the process of sample forming. Brick samples were stored in the laboratory in natural conditions. The engineering properties of fly ash-based geopolymer bricks including compressive strength, unit weight, water absorption, and water permeability were tested complying with TCVN 6477 [25]. The uniformity of brick samples was assessed through the ultrasonic pulse velocity test (UPV). The microstructure of brick samples was evaluated by using the scanning electron microscope. It is noticed that the compressive strength and UPV of bricks were tested at $3,7,14$, and 28 days, whereas others were conducted at 28 days. The average value of three measurements is used as the reported value in this study. The reported compressive strength values were multiplied by the shape adjustment coefficient of 0.7 as stipulated by TCVN 6477 [25].

Based on TCVN 6477 [25], the water permeability was calculated by the following equation:

$$
H=\frac{V}{S \times T}
$$

In which, $H=$ water permeability $\left(\mathrm{L} / \mathrm{m}^{2} . \mathrm{h}\right) ; V=$ the volume of water absorbed through the brick sample (L); $S=$ surface area of the brick sample contacted with water $\left(\mathrm{m}^{2}\right) ; T=$ testing time $(h)$. It is noticed that a brick sample was saturated in water before the water permeability test. The experiment of water permeability was conducted under pressure of $25 \mathrm{~cm}$ water column height.

\section{RESULTS AND DISCUSSION}

\subsection{Compressive Strength}

Figure 3 shows the compressive strength of fly ash-based geopolymer brick samples, which was developing over time due to the process of geopolymerization. The 28-day compressive strength of bricks ranged from 10.1 MPa to $25.2 \mathrm{MPa}$. It is noticed that compressive strength of around $7.5 \mathrm{MPa}$ is used in real practice. It means that all fly ash-based geopolymer bricks produced in this study have a compressive strength of above $10 \mathrm{MPa}$, classifying as a high grade of brick [7]. In addition, as an increment in $\mathrm{NaOH}$ concentration, the compressive strength of brick samples increased. This result is in line with results from previous studies [10-13]. The high concentration of $\mathrm{NaOH}$ solution encouraged the dissolution rate of silicon and aluminum ions, thus enhancing the formation of aluminosilicate in geopolymerization $[10,12]$. That resulted in improving the compressive strength of geopolymer brick samples. It is worth noting that the 28-day compressive strength of brick samples is higher than $25 \mathrm{MPa}$ when using $\mathrm{NaOH}$ solution of $12 \mathrm{M}$ as an alkaline activator. This strength value is as high as the strength of normal hardened concrete. This is demonstrated for the use of fly ash even with a high loss on ignition to produce geopolymer bricks. 


\subsection{Unit Weight}

Figure 4 shows the unit weight of fly ash-based geopolymer bricks corresponding to $\mathrm{NaOH}$ concentrations. The unit weight of brick samples changed from 2.1 to $2.2 \mathrm{~T} / \mathrm{m}^{3}$, which values are similar to that of practical cement concrete bricks manufactured in Vietnam. When $\mathrm{NaOH}$ concentration increased, the unit weight of brick samples slightly increased. This is due to the higher amount of chippings and a higher density of $\mathrm{NaOH}$ in brick mixtures with high $\mathrm{NaOH}$ concentration (Table 1). As mentioned above, $\mathrm{NaOH}$ solutions with concentrations of 5, 8, 10 and $12 \mathrm{M}$ have densities of $1.20,1.28,1.33$, and $1.38 \mathrm{~T} / \mathrm{m}^{3}$, respectively.

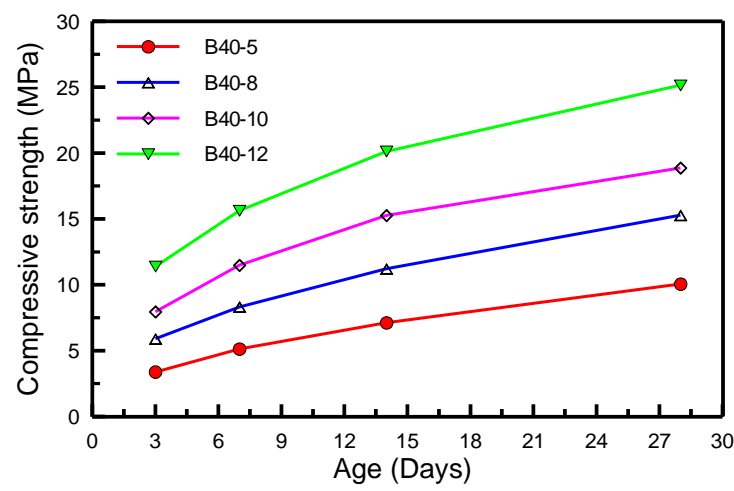

Figure 3. Compressive strength of fly ashbased geopolymer bricks

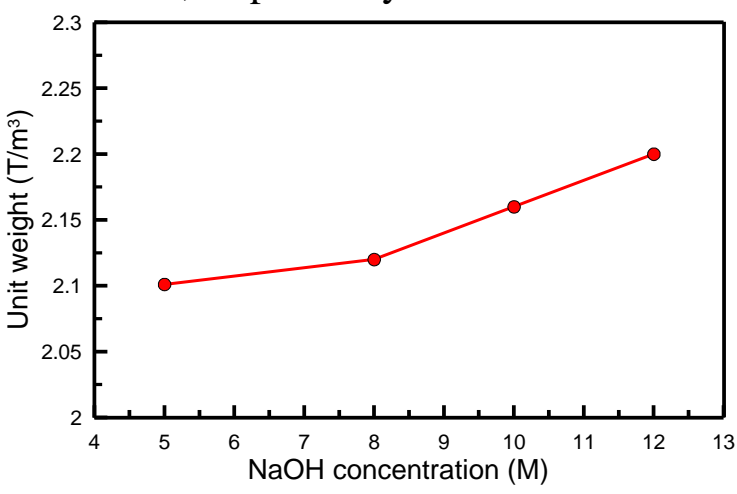

Figure 4. Unit weight of fly ash-based geopolymer bricks

\subsection{Water Absorption}

As well as compressive strength, water absorption is an important property of building bricks. Because it is associated with water permeability and chemical attack resistance of bricks. That is why the Vietnamese standard for concrete brick limiting the maximum water absorption of lower than $14 \%$ [25]. The effect of $\mathrm{NaOH}$ concentration on the water absorption of fly ashbased geopolymer bricks is shown in Figure 5. As an increment of $\mathrm{NaOH}$ concentration, the water absorption of brick samples reduced. As mentioned above, the high $\mathrm{NaOH}$ concentration enhanced the formation of aluminosilicate, which leads to increasing in compressive strength and reducing in water absorption of geopolymer bricks.

The water absorption of geopolymer bricks in this study ranged from $3.1 \%$ to $9.4 \%$, much lower than the maximum value stipulated by TCVN 6477 [25]. Both water absorption and compressive strength are related to $\mathrm{NaOH}$ concentration, thus they also have a relationship. Figure 6 shows the relationship between water absorption and compressive strength, it is described as a linear equation of $y=-0.42 x+12.86$ with $R^{2}=0.91$.

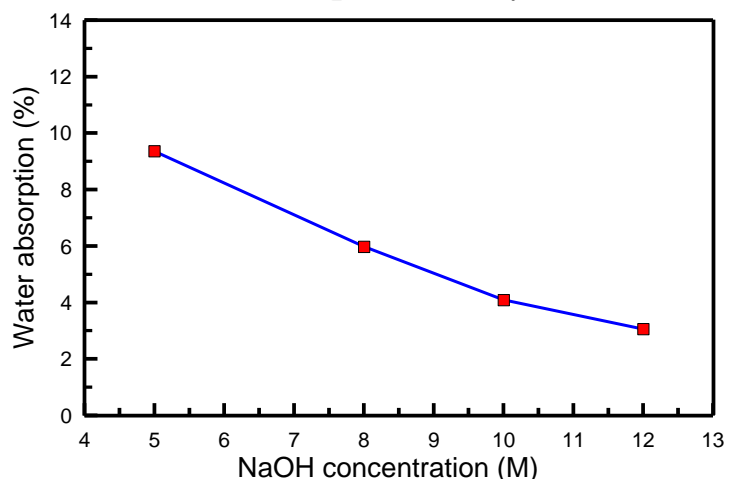

Figure 5. Effect of $\mathrm{NaOH}$ concentrations on water absorption of brick samples

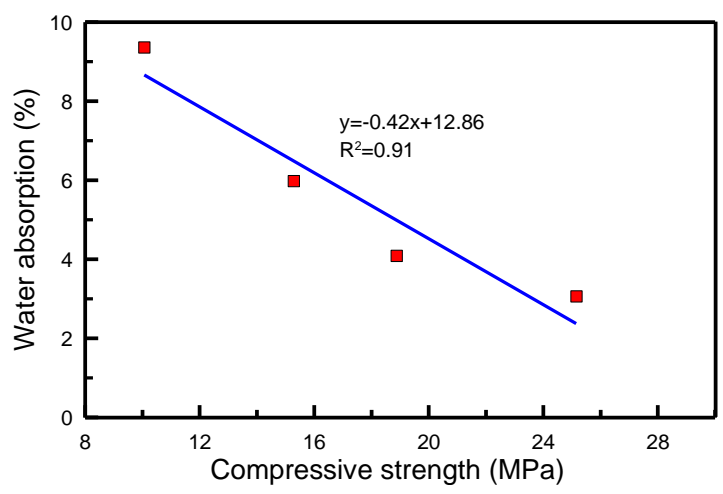

Figure 6. Relationship between water absorption and compressive strength 


\subsection{Water Permeability}

As well as water absorption, water permeability directly reflects the durable properties of bricks related to chemical attack resistance. The lower water permeability, the greater resistance to chemical attack. Therefore, the Vietnamese standard also limits the value of water permeability below $16 \mathrm{~L} / \mathrm{m}^{2} . \mathrm{h}$ [25]. The water permeability of geopolymer brick samples corresponding to various $\mathrm{NaOH}$ concentrations is illustrated in Figure 7. The water permeability reduced as increasing $\mathrm{NaOH}$ concentration. This is attributable to the high formation of aluminosilicate, preventing water absorbed through the brick sample. The water permeability of brick samples in this study varied from 0.23 to $1.84 \mathrm{~L} / \mathrm{m}^{2}$.h, significantly lower than the allowance value stipulated by TCVN 6477 [25] as mentioned above.

\subsection{Ultrasonic Pulse Velocity}

The relative quality of fly ash-based geopolymer bricks in this study was evaluated based on the ultrasonic pulse velocity (UPV) test. The UPV values of all brick samples are shown in Figure 8. At 28 days, the UPV values of brick samples ranged from $2500 \mathrm{~m} / \mathrm{s}$ to $4521 \mathrm{~m} / \mathrm{s}$ corresponding to $\mathrm{NaOH}$ concentration changed from $5 \mathrm{M}$ to $12 \mathrm{M}$. In other words, the quality of geopolymer brick enhanced with increasing $\mathrm{NaOH}$ concentration. Similarly, this result is associated with the formation of aluminosilicate in the process of geopolymerizaion. That resulted in increasing compressive strength, reduction in water absorption and water permeability values as aforementioned. Based on results from previous studies, the UPV values of bricks ranged from $1700-2100 \mathrm{~m} / \mathrm{s}$ and $2060-3150 \mathrm{~m} / \mathrm{s}$ corresponding to the compressive strength of 6.0-15.0 MPa and 7.7-26.3 MPa [26-27]. In this study, brick samples with UPV values of $2500-4521 \mathrm{~m} / \mathrm{s}$ had the compressive strength values of 10.1-25.2 MPa. It means that all geopolymer brick samples produced in this study are classified as good quality.

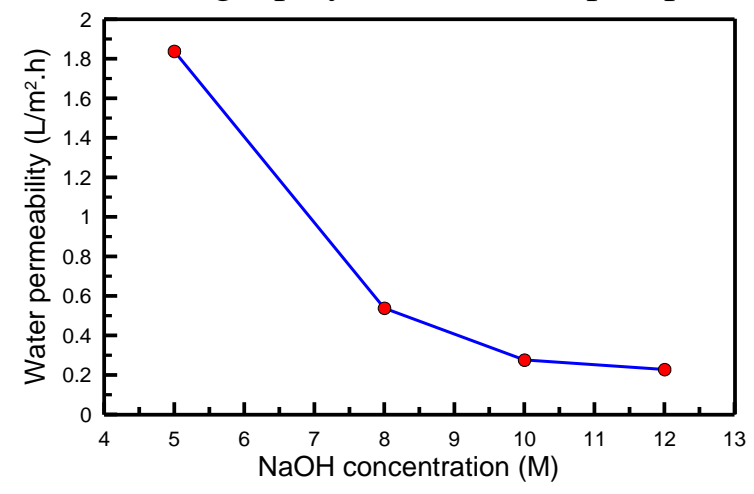

Figure 7. Effect of $\mathrm{NaOH}$ concentrations on water permeability of brick samples

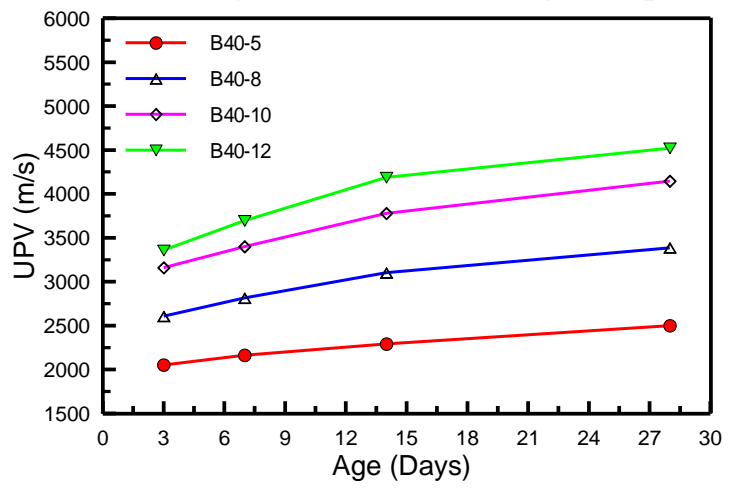

Figure 8. Ultrasonic pulse velocity of fly ashbased geopolymer bricks

\subsection{SEM Observation}

Figure 9 shows the scanning electron micrograph images of all brick samples with a magnification of 2000 times. Many free fly ash particles as seen in spherical shapes and many voids were observed in brick samples with $\mathrm{NaOH}$ concentrations of 5 and $8 \mathrm{M}$. It means that with a low concentration of $\mathrm{NaOH}$ solution, fly ash is not effective to joint in geopolymeric reaction. For geopolymer brick samples using $\mathrm{NaOH}$ of 10 and $12 \mathrm{M}$, free fly ash was fewer and geopolymer formations were seen as large textures. This finding is related to other properties of fly ash-based geopolymer bricks as reported above. 


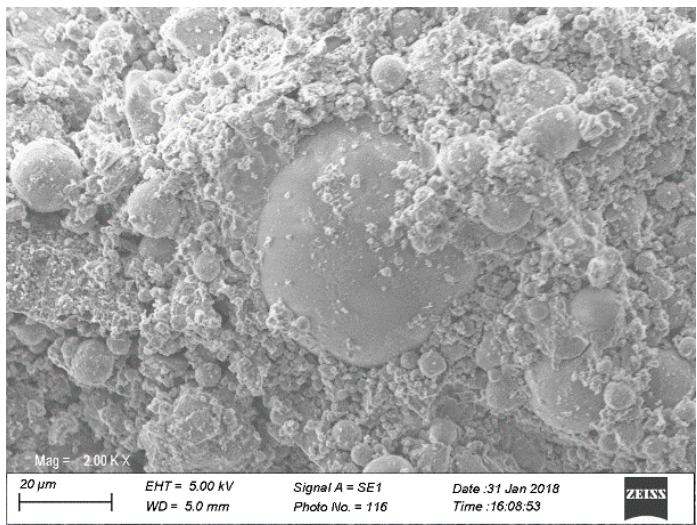

a) B40-5

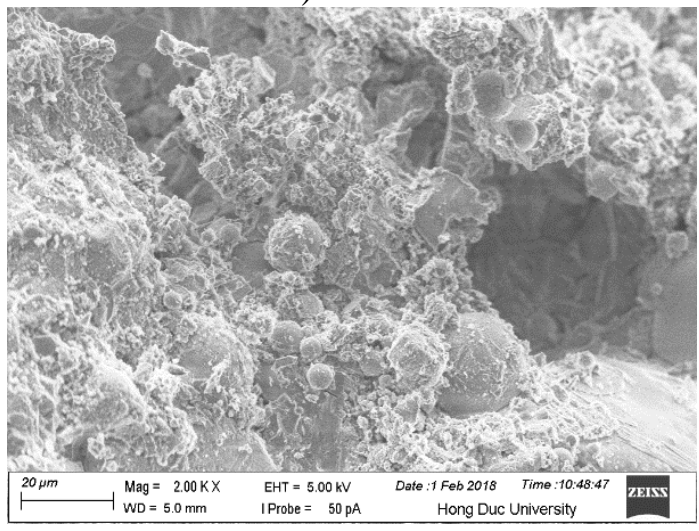

c) B $40-10$

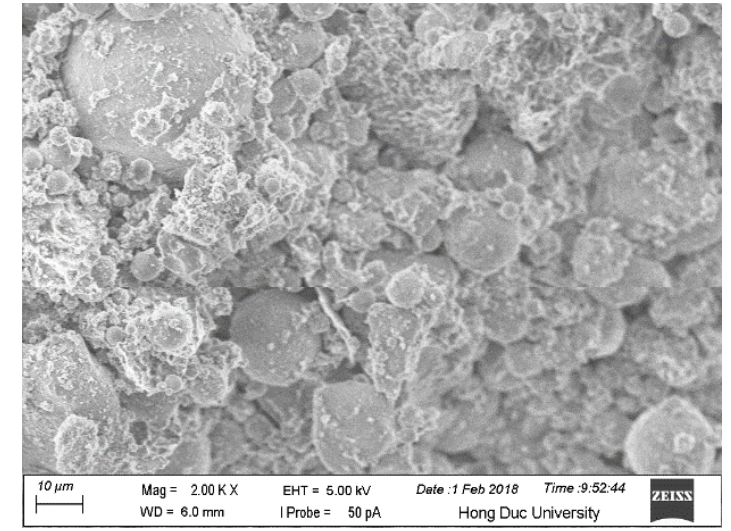

b) B40-8

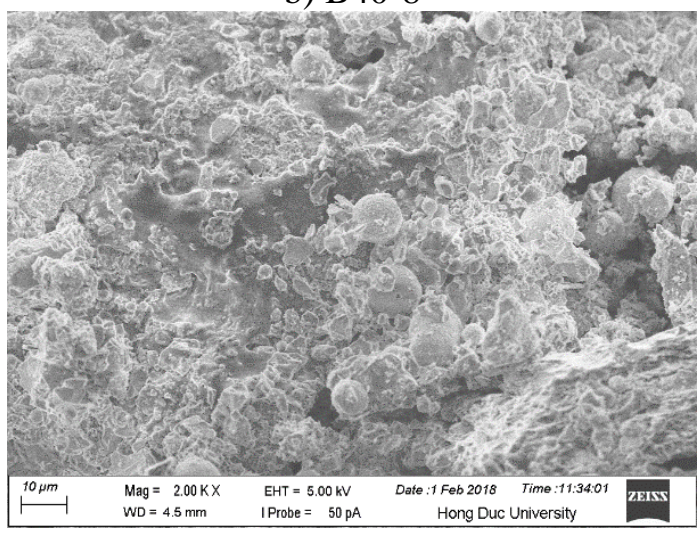

d) B40-12

Figure 9. SEM micrographs of fly ash-based geopolymer brick samples

\section{CONCLUSION}

In this study, the fly ash and sodium hydroxide solution were used as alkaline-activated materials to produce geopolymer bricks. Based on the obtained results, the following conclusions may be drawn:

- All geopolymer brick samples manufactured in this study were classified as good quality with compressive strength of above $10.1 \mathrm{MPa}$, water absorption of below $9.4 \%$, water permeability of below $1.84 \mathrm{~L} / \mathrm{m}^{2} . \mathrm{h}$, and ultrasonic pulse velocity of above $2500 \mathrm{~m} / \mathrm{s}$.

- As an increment in $\mathrm{NaOH}$ concentration, the compressive strength, unit weight, and ultrasonic pulse velocity of geopolymer bricks increased. The adverse trend was obtained for the water absorption and water permeability of geopolymer bricks.

- As observed in SEM images, the use of high $\mathrm{NaOH}$ concentration encouraged the fly ash joining in geopolymeric reaction, enhancing the properties of geopolymer bricks.

\section{ACKNOWLEDGMENTS}

The experimental works were carried out at the construction material laboratory of the Department of Engineering and Technology, Hong Duc University. The authors would like to thank Ms. Nguyen Thi Thanh, a lecturer of Hong Duc University for her assistance in the experimental work. 


\section{REFERENCES}

[1] J. Opon, M. Henry, "An indicator framework for quantifying the sustainability of concrete materials from the perspectives of global sustainable development", Journal of Cleaner Production, 218, pp. 718-737, 2019.

[2] L.K. Turner, F.G. Collins, "Carbon dioxide equivalent (CO2-e) emissions: a comparison between geopolymer and OPC cement concrete", Construction and Building Materials, 43, pp.125-130, 2013.

[3] A. Heath, K. Paine, M. McManus, "Minimising the global warming potential of clay based geopolymers", Journal of Cleaner Production, 78, pp. 75-83, 2014.

[4] R.S. Rafael, M.A. Johanna, M.G. Ruby, M. Edgar, "Life cycle assessment (LCA) of an alkali-activated binary concrete based on natural volcanic pozzolan: a comparative analysis to OPC concrete", Construction and Building Materials, 176, pp. 103-111, 2018.

[5] D.A. Salas, A.D. Ramirez, N. Ulloa, H. Baykara, A.J. Boero, "Lifecycle assessment of geopolymer concrete", Construction and Building Materials, 190, pp. 70-177, 2018.

[6] J.L. Provis, "Alkali-activated materials", Cement and Concrete Research, 114, pp. 40-48, 2018.

[7] S.H. Ngo, T.T.T. Le, T.P. Huynh, "Effect of unground rice husk ash on properties of sodium hydroxide-activated-unfired building bricks", International Journal of Civil Engineering and Technology, 9(9), pp 1582-1592, 2018.

[8] F.A. Memon, M.F. Nuruddin, S. Khan, N. Shafiq, T. Ayub, "Effect of sodium hydroxide concentration on fresh properties and compressive strength of self-compacting geopolymer concrete", Journal of Engineering Science and Technology, 8(1), pp. 44-56, 2013.

[9] P. Chindaprasirt, A. Jaturapitakkul, W. Chalee, U. Rattanasak "Comparative study on the characteristics of fly ash and bottom ash geopolymers", Waste Management, 29(2), pp 539-543, 2009.

[10] U. Rattanasak, P. Chindaprasirt, "Influence of $\mathrm{NaOH}$ solution on the synthesis of fly ash geopolymer", Minerals Engineering, 22(12), pp. 1073-1078, 2009.

[11] N.S.H. Muhammad, A.A. Mustafa, Y. Tao, "Effect of fly ash characteristics and alkaline activator components on compressive strength of fly ash-based geopolymer mortar", Construction and Building Materials, 175, pp. 41-54, 2018.

[12] S. Hanjitsuwan, S. Hunpratub, P. Thongbai, S. Maensiri, V. Sata, P. Chindaprasirt, "Effect of $\mathrm{NaOH}$ concentrations on physical and electrical properties of high calcium fly ash geopolymer paste", Cement and Concrete Composites, 45, pp. 9-14, 2014.

[13] M. Palacios, M.M. Alonso, C. Varga, F. Puertas, "Influence of the alkaline solution and temperature on the rheology and reactivity of alkali-activated fly ash pastes", Cement and Concrete Composites, 95, pp. 277-284, 2019.

[14] X. Guo, H. Shi, W.A. Dick, "Compressive strength and microstructural characteristic of class C fly ash geopolymer", Cement and Concrete Composites, 32, pp. 142-147, 2010.

[15] M.A. Yazdi, M. Liebscher, S. Hempel, J. Yang, V. Mechtcherine, "Correlation of microstructural and mechanical properties of geopolymers produced", Construction and Building Materials, 191, pp. 330-341, 2018.

[16] K. Somna, C. Jaturapitakkul, P. Kajitvichyanukul, P. Chindaprasirt, "NaOH-activated ground fly ash geopolymer cured at ambient temperature", Fuel, 90, pp. 2118-2124, 2011. 


\section{Si-Huy Ngo}

[17] J.E. Oh, Y. Jun, Y. Jeong, "Characterization of geopolymers fromcompositionally and physically different Class F fly ashes", Cement and Concrete Composites, 50, pp.16-26, 2014.

[18] X.Y. Zhuang, L. Chen, S. Komarneni, C.H. Zhou, D.S. Tong, H.M. Yang, W.H. Yu, H. Wang, "Fly ash-based geopolymer: clean production,properties and applications", Journal of Cleaner Production, 125, pp. 253-267, 2016.

[19] A. Kumar, S. Kumar, "Development of paving blocks from synergistic use of red mud and fly ash using geopolymerization", Construction and Building Materials, 38, pp. 865-871, 2013.

[20] C. Freidin, "Cementless pressed blocks from waste products of coal-firing power station", Construction and Building Materials, 21(1), pp. 12-18, 2017.

[21] C.L. Hwang, T.P. Huynh, "Investigation into the use of unground rice husk ash to produce eco-friendly construction bricks", Construction and Building Materials, 93, pp. 335-341, 2015.

[22] C.L. Hwang, T.P Huynh, "Evaluation of the performance and microstructure of ecofriendly construction bricks made with fly ash and residual rice husk ash", Advances in Materials Science and Engineering, 2015, pp. 1-11, 2015.

[23] C.L. Hwang, T.P. Huynh, Y. Risdianto, "An application of blended fly ash and residual rice husk ash for producing green building bricks", Journal of the Chinese Institute of Engineering, 39(7), pp. 850-858, 2016.

[24] ASTM C618, "Standard specification for coal fly ash and raw or calcined natural pozzolan for use in concrete", 2005.

[25] Vietnamese standard TCVN 6477, "Concrete brick", Ministry of Science and Technology, 2016.

[26] A.A. Shakir, S. Naganathan, K.N. Mustapha, "Properties of bricks made using fly ash, quarry dust and billet scale", Construction and Building Materials, 41, pp. 131-138, 2013.

[27] P. Turgut, "Masonry composite material made of limestone powder and fly ash", Powder Technology, 204(1), pp 42-47, 2010. 